\title{
ПСИХОЛОГО-ПЕДАГОГІЧНІ ОСОБЛИВОСТІ МОДЕЛЮВАННЯ ПРОФЕСІЙНОЇ КОМПЕТЕНТНОСТІ СТУДЕНТІВ-МЕДИКІВ У ПРОЦЕСІ ПРОФЕСІЙНОГО СТАНОВЛЕННЯ
}

\section{Лазуренко Олена Олексївна}

Кандидат психологічних наук, старший викладач кафедри загальної і медичної психології та педагогіки Національного медичного університету імені О.О. Богомольия, м. Київ (Україна)

\begin{abstract}
Анотація. Стаття присвячена проблемі професійного становлення фахівия. Визначено сутність та етапи професійного становлення. Розглянуто стадії розвитку лікаря у професійній сфері, етапи формування професійних здібностей у прочесі оволодіння професією. Наведена загальна характеристика професійного становлення та рівні професіоналізму. Презентовано модель професійного становлення та формування професійної компетентності майбутнього лікаря. Представлено аналіз етапів професійного становлення фахівців, визначено психолого-педагогічні особливості формування професійної компетентності майбутніх медиків на етапі професійного становлення. Окреслено етапи професіогенезу особистості лікаря від етапу професійної психологічної готовності та адаптації до етапу професійної майстерності. Проаналізовані психолого-педагогічні особливості професійного становлення майбутнього лікаря дозволяють говорити про можливість розвитку професійної компетентності фахівия. Зроблено припущення, щчо здобуття знань, вмінь та навичок, пов'язаних з професійною компетентністю лікаря, може сприяти розвитку професіоналізму, як інтегральної якості особистості фахівия. Зроблено висновки та визначені перспективи подальшого вивчення особливостей професіогенезу лікаря.
\end{abstract}

Ключові слова: професійне становлення, професіогенез, професійна компетентність, професіоналізм, професійна підготовка, особистість майбутнього лікаря.

Постановка проблеми. Одним із завдань системи національної вищої освіти є підготовка висококваліфікованих фахівців, основним показником якої є професіоналізм, що виявляється, $з$ одного боку, у набутих знаннях, вміннях та навичках, необхідних для успішного їх використання у подальшій діяльності, на практиці, а, з іншого - у формуванні всебічно розвиненої особистості. Кінцевим, найвищим результатом професійного становлення лікаря є його професіоналізм, що виявляється в абсолютній психологічній готовнос- 
ті до ефективного виконання своїх обов'язків. Специфічними чинниками розвитку особистості студента у вищому медичному навчальному закладі $є$ набуття вищої освіти, а також професійне становлення майбутнього лікаря.

Соціальна ситуація в суспільстві, пов'язана 3 новими політичними та економічними викликами, вимагає високого рівня професіоналізму та компетентності медичних кадрів, що, в свою чергу, можливо лише за умови докорінної зміни існуючої системи вищої освіти, формування нових ціннісних пріоритетів у професійній підготовці спеціалістів. Ми переконані, що новий вектор навчання у вищому медичному навчальному закладі повинен бути спрямований не лише на оволодіння фаховими знаннями, вміннями та навичками, що, безумовно, складає підгрунтя у професійній компетентності лікаря, а й формування мотиваційної та ціннісної сфер особистості, становлення іiі як професіонала, що володіє широким спектром необхідних фахових, особистісних, комунікативних та соціальних компетенцій. Саме такий підхід допоможе зробити підготовку спеціаліста дійсно особистісно-орієнтованою, оскільки активізує процеси самопізнання та самоздійснення, оптимізує діяльність та виділяє саме компетентність фахівця як основний ціннісний мотив навчання [14].

Аналіз останніх досліджень і публікацій. Проблема дослідження професійного становлення знаходиться у постійному центрі уваги багатьох вчених, які визначають сутність та етапи професійного становлення (С. Зеєр, Е. Климов, А. Маркова та ін.), психологічні особливості (А. Маркова, Л. Мітіна та ін.), психолого-педагогічні умови та чинники професійного розвитку особистості (Л. Мітіна, Л. Виготський, О. Леонтьєв, С.Рубінштейн, Л. Орбан, Л. Рибалко, О. Кокун). Так, Е.О. Климов основними стадіями розвитку людини як суб'єкта праці (з початку опанування професією) виділяє такі, як: «оптант» - стадія підготовки до життя, до праці, свідомого і відповідального планування і вибору професійного шляху; «адепт» - стадія професійної підготовки, яку проходить більшість випускників шкіл; «адаптант» - стадія входження в професію після завершення професійного навчання; «інтернал»- стадія входження в професію як повноцінного колеги, здатного стабільно працювати на нормальному рівні; «майстер» стадія, коли працівник помітно виділяється на загальному фоні серед інших співробітників, представників галузі (кращий серед кращих); «авторитет» - стадія, яка означає, що працівник став «кращим серед майстрів»; «наставник» - стадія, яка характеризує вищий рівень праці, працівник не просто чудовий фахівець у своїй галузі, але і здатний передати кращий свій досвід [3].

Чотири етапи у формуванні професійних здібностей у процесі оволодіння професією виділяє В. Орел: перший - вступ до діяльності, коли учень освоює діяльність, не маючи 
власного досвіду, коли система професійних здібностей ще не сформована, провідною професійно-важливою якістю $є$ довготривала пам'ять і ряд спеціальних професійно-важливих властивостей, кількість яких $є$ обмеженою; другий - первинна професіоналізація - по мірі надбання індивідуального досвіду відбувається розвиток провідних професійно-важливих властивостей першого етапу; при цьому зростає роль тих професійних якостей, які відповідають за прийом інформації; третій - стабілізація - професійні здібності, що відповідають за прийом і переробку інформації, виступають на перший план, у той час як частина професійних здібностей випадає з структур професійних якостей; при цьому дані якості в кількісному плані можуть залишатися на високому рівні; на цьому рівні діяльність починає реалізовуватися в індивідуальному способі їі виконання; суб'єкт звертає більше уваги на прогнозування і планування діяльності щодо іiі виконавчої частини; четвертий - вторинна професіоналізація - відбувається зміна професійно-важливих властивостей, суб'єкт переходить від системи професійних здібностей, що реалізовують діяльність до накопичення професійного досвіду, до системи професійноважливих властивостей, заснованій на особистому досвіді [12].

За А. К. Марковою, можна виділити такі рівні професіоналізму: допрофесіоналізм (людина вже працює, але не має повного набору якостей справжнього професіонала); про- фесіоналізм (людина - професіонал, тобто стабільно працює і виконує усе, що від неї вимагається); суперпрофесіоналізм (творчість, особистісний розвиток, вершина професійних досягнень); непрофесіоналізм, псевдопрофесіоналізм (зовні досить активна діяльність, але при цьому людина або робить багато помилок у роботі, або сама деградує як особистість); післяпрофесіоналізм (людина може виявитися «професіоналом у минулому», «експрофесіоналом», а може бути наставником для інших фахівців). Цією ж дослідницею виділені й етапи оволодіння професією: адаптація до професії; самоактуалізація в професії пристосування людини до професії; гармонізація з професією - людина легко виконує завдання за засвоєними технологіями; перетворення, збагачення своєї професії - справжня творчість припускає пошук нових, більш досконалих способів досягнення результату; вільне володіння кількома професіями; творче самовизначення себе як особистості - прагнення реалізувати свою головну життєву ідею [10].

В. О. Толочек основними етапами процесу формування професійної придатності людини вважає наступні: трудове виховання i навчання (підготовка дитини, підлітка до праці і вибору професії); професійна орієнтація (допомога у виборі професії: освіта, консультація, корекція професійних планів, оптація знаходження мінімального досвіду в конкретній роботі та ін.); професійний відбір (визначення ступеня придатності людини до 
даної професії, трудової посади, робочого місця); професійна підготовка (обгрунтування i розробка рекомендацій, програм навчання, методик, засобів та ін.); професійна адаптація (розробка засобів, методів, критеріїв оцінки успішності діяльності суб'єкта, виявлення критичних факторів адаптації, кризових періодів; у цілому - психологічний супровід суб'єкта на початкових етапах його професійної кар'єри); професійна діяльність (забезпечення раціональної організації іiі умов, процесів, безпеки, оптимальних ділових контактів і взаємодіiі, розвиток професіоналізму, ефективності, задоволеності працею, охорони праці та ін.); професійна атестація (періодична оцінка кваліфікації з метою обгрунтування рекомендацій 3 посадових переміщень, оплати праці, перепідготовки та ін.); професійна реабілітація (відновлення стану психічного і фізичного здоров'я тощо) [13].

У структурі проблеми професійного самовизначення О. І. Вітковська виділяе три головні компоненти: проблему самореалізації; проблему вибору і проблему адаптації. Розв'язання проблеми самореалізації здійснюється особистістю шляхом самопізнання і саморозуміння, усвідомлення своєї «реалізаційної спрямованості» і проектування іiі на сфери професійної діяльності. Свідомий вибір здійснюється особистістю самостійно у результаті формування ціннісної вихідної позиції і розв'язання мотиваційних протиріч. Адаптивний аспект проблеми професійного самовизначен- ня полягає у процесах узгодження всіх елементів індивідуальної профорієнтаційної ситуації: ціннісно-смислової структури особистості, іiї здібностей і потреб, актуальних процесів іiі розвитку, обставин і ситуації, які охоплюють як соціальне середовище у цілому, так і існуючу професійну структуру [1]. На відміну від інших, М. С. Пряжников запропонував свою змістовно-процесуальну модель професійного самовизначення, основними складовими якої $\epsilon$ усвідомлення цінності суспільно-корисної праці і необхідності професійної підготовки (цінністно-моральна основа самовизначення); орієнтування в соціально-економічній ситуації і прогнозування престижності обраної праці; загальне орієнтування у світі професійної праці і виділення професійної мети - мрії; визначення найближчих професійних цілей як етапів і шляхів до віддаленої мети; інформування про професії та спеціальності, відповідні професійні навчальні заклади і місця працевлаштування; уявлення про перешкоди, що ускладнюють досягнення професійних цілей, а також знання своєї гідності, що сприяють реалізації планів і перспектив; наявність системи резервних варіантів вибору на випадок невдачі за основним варіантом самовизначення; початок практичної реалізації особистої професійної перспективи і постійне коригування планів за принципом зворотного зв'язку. Також вченим було запропоновано сім типів самовизначення особистості. Самовизначення в конкретній трудовій функції. Для цього типу самовизна- 
чення характерна реалізація себе в рамках виконуваної діяльності. Фахівець знаходить сенс своєї діяльності в якісному виконанні окремих трудових функцій чи операцій. Воля вибору i діапазон дій тоді мінімальні. Для багатьох працівників така одноманітна i монотонна праця майже нестерпна. Тому організатори виробництва намагаються збагатити таку працю додатковими функціями за рахунок зміни характеру виконуваних операцій, підсилюють кооперативний початок у діяльності, розширюючи тим самим можливості самореалізації працівників. Разом з тим, деякі люди отримають задоволення і від такої одноманітної праці. Самовизначення на певному трудовому посту передбачає виконання досить різноманітних функцій. Трудовий пост характеризується визначеними правами і виробничими завданнями, обмеженим виробничим середовищем, що включає засоби праці. Можливість самореалізації в рамках виконуваної діяльності значно вище, ніж у першому випадку. Зміна конкретного трудового посту негативно позначається на якості та продуктивності праці і викликає незадоволеність працівника. Самовизначення на рівні конкретної спеціальності передбачає порівняно безболісну зміну різних трудових постів і в цьому змісті розширює можливості самореалізації особистості. Самовизначення в конкретній професії означає, що працівник здатен виконувати схожі, суміжні види трудової діяльності. Тому, у порівнянні 3 попереднім типом самовизначення, працівник обирає вже спеціальності, а не лише трудові пости. Життєве самовизначення. До цього типу самовизначення, крім професійної діяльності, відносяться навчання, дозвілля, змушене безробіття та ін. Тут мова йде про вибір способу життя людини. Слід зазначити, що чимало людей бачать сенс свого життя у позапрофесійній діяльності. Життєве самовизначення передбачає не лише вибір і реалізацію людиною тих чи інших соціальних ролей, але і вибір стилю життя. У цьому випадку професія може стати засобом реалізації певного способу життя. Особистісне самовизначення. Розглядається як вищий прояв життєвого самовизначення, коли людина стає господарем ситуації і усього свого життя. Особистість у цьому випадку ніби піднімається і над професією, i над соціальними ролями та стереотипами. Людина не просто опановує соціальну роль, а створює нові ролі, коли оточуючі люди говорять про неї не як про гарного інженера, лікаря, педагога, а просто як про шановану людину - унікальну і неповторну особистість. Це знаходження самобутнього «образу Я», постійний розвиток цього образу і ствердження його серед оточуючих. Самовизначення особистості в культурі - вищий прояв особистісного самовизначення. Тут обов'язковою є внутрішня активність, спрямована на «продовження себе в інших людях», що в якомусь сенсі дозволяє говорити про соціальне безсмертя людини. Цей тип самовизначення виявляється у значному внеску особистості у 
розвиток культури, що розуміється у найширшому змісті (виробництво, мистецтво, наука, релігія тощо)[11].

В цілому, основними складовими професійних досягнень можна вважати: освіченість; системність і аналітичність мислення (уміння прогнозувати розвиток ситуації і передбачати результат рішень, уміння мислити масштабно й реалістично одночасно); комунікативні уміння й навички ефективної міжособистісної взаємодії; високий рівень саморегуляції (уміння керувати своїм станом, стійкість до стресів); ділова спрямованість (активність, наполегливість і цілеспрямованість, спрямованість на прийняття рішень, уміння розв'язувати нестандартні проблеми й задачі, прагнення до постійного підвищення професіоналізму); чітка Я-концепція, реалістичне сприйняття своїх здібностей і можливостей, адекватна та висока самоповага.

Здійснений Е. Ф. Зєєром аналіз дав можливість виділити чотири основні особистісні складові професійного становлення фахівця [2]. Перша - спрямованість особистості, яка характеризується системою домінуючих потреб, мотивів, ставлень, ціннісних орієнтацій та установок. Компонентами професійної спрямованості є: мотиви (наміри, інтереси, схильності, ідеали); ціннісні орієнтації (зміст праці, заробітна плата, добробут, кваліфікація, кар'єра, соціальний стан тощо); професійна позиція (ставлення до професії, установки, очікування і готовність до професійного розвитку); соціа- льно-професійний статус. Друга - професійна компетентність - сукупність професійних знань, умінь, а також способів виконання професійної діяльності. Її основні компоненти: соціально-правова компетентність (знання й уміння у галузі взаємодії із суспільними інститутами і людьми, а також володіння прийомами професійного спілкування і поведінки); спеціальна компетентність (готовність до самостійного виконання конкретних видів діяльності, уміння вирішувати типові професійні задачі й оцінювати результати своєї праці, здатність самостійно здобувати нові знання й уміння за фахом); персональна компетентність (здатність до постійного професійного росту i підвищення кваліфікації, а також реалізації себе в професійній праці); ауто компетентність (адекватне уявлення про свої соціальнопрофесійні характеристики і володіння технологіями подолання професійних деструкцій); екстремальна професійна компетентність (здатність діяти в умовах, що раптово ускладнилися, при аваріях, порушеннях технологічних процесів). Третя - професійно важливі якості - це психологічні якості особистості, що визначають продуктивність (продуктивність, якість, результативність та ін.) діяльності. Вони багатофункціональні i разом 3 тим кожна професія має свій набір цих якостей. Четверта - професійно важливі психофізіологічні властивості (зорово-рухова координація, окомір, нейротизм, екстраверсія, реактивність, енергетизм тощо). Розвиток цих 
властивостей відбувається вже в ході оволодіння діяльністю. У процесі професіоналізації одні психофізіологічні властивості визначають розвиток професійно важливих якостей, інші, професіоналізуючись, здобувають самостійне значення.

Виділення невирішених раніше частин загальної проблеми, яким присвячується стаття. Аналіз наукових джерел свідчить про те, що проблема дослідження особливостей професійної компетентності лікарів у процесі професійного становлення та їі впливу на професійну діяльність залишається недостатньо дослідженою, а недостатній рівень розвитку професійної компетентності випускників медичних університетів негативно впливає на ефективність майбутньої професійної діяльності.

Мета статті: представити аналіз етапів професійного становлення фахівців, визначити психолого-педагогічні особливості та етапи формування професійної компетентності майбутніх медиків на етапі професійного становлення.

Виклад основного матеріалу дослідження. Становлення професіоналізму майбутнього фахівця залежить від навчальнопізнавальної діяльності, яка охоплює не лише оволодіння системою знань, набуття вмінь та навичок, а й постійне самовдосконалення. У сучасному загальноприйнятому науковому розумінні становлення - це філософська категорія, що виражає мінливість речей, явищ, їх неперервний перехід в інше, набуття нових форм у процесі розвитку, наближення до певного стану. Цей термін привернув до себе увагу багатьох вчених. Частіше за все становлення характеризується нерозривним зв'язком 3 розвитком чи формуванням, водночас, об'єднуючи чи, навіть, замінюючи ці терміни, зокрема, коли мова йде про становлення і розвиток особистості.

Сутність категорії «професійне становлення» може бути виявлена у їі співставленні із категоріями «розвиток» та «формування». Проведений аналіз літературних джерел показав, що розвиток визначається як процес кількісних та якісних змін, удосконалення пізнавальних здібностей, збагачення світогляду. Розвиток особистості - це об'єктивний процес становлення фізичних та духовних сил людини, які забезпечують реалізацію ії̈ внутрішнього потенціалу, їі сутності та призначення, процес зміни індивіда у результаті його соціалізації. У процесі розвитку особистості відбувається становлення іiї цілісності, що забезпечує неперервність, спадкоємність всіх періодів розвитку особистості. Отже, особистість розвиваючись, формується, набуває цілісну систему соціальних властивостей.

Під формуванням зазвичай розуміють сукупність прийомів і способів соціального впливу на індивіда з метою створення у нього системи певних ціннісних орієнтацій, переконань, професійно важливих якостей. Це процес становлення соціально важливих якостей 
особистості, iї переконань, поглядів, здібностей, тих властивостей, що виникають в результаті розвитку. Факторами формування особистості зазвичай $є$ ті суперечності, що стають рушійною силою іiі розвитку.

Якщо розглядати професіоналізм як систему професійних знань, вмінь, навичок, їх особистісного наповнення, можна сміливо розглядати підготовку майбутніх фахівців як період професійного становлення. Цей процес індивідуального становлення професійно важливих якостей та здібностей, професійних знань та вмінь, що призводить до самореалізації особистості у професії. Саме на стадії виконання самостійної професійної діяльності людина досягає свого професійного розвитку, який залежить від особливостей діяльності та індивідуальних можливостей конкретної людини. Таким чином, процес професійного становлення є індивідуальним для кожного.

Професійне становлення особистості це цілісний динамічний процес від формування професійного самовизначення до повної реалізації себе у діяльності. Основним протиріччям професійного становлення є протиріччя між сформованими властивостями особистості та об’єктивними вимогами провідної діяльності, яка обумовлює подальший розвиток особистості, призводить до формування нових якостей особистості. Джерелом професійного становлення виступають і протиріччя між досягнутим рівнем розвитку особистості та вимогами, що висуває колектив, суспільство, навчальна діяльність до системи вже сформованих знань, навичок, а також до індивідуально-психологічних властивостей особистості. Професійне становлення передбачає формування професійно важливих якостей, як тих, що пов’язані з видом діяльності, так і особистісні, професійно важливі для професійної діяльності. Тому професійне становлення особистості має два вектори - освітній та особистісного зростання.

Професіоналізм - неодмінна складова компетентності у конкретній діяльності. Компетентність - у перекладі 3 англійської - це сукупність компетенцій, наявність знань та досвіду для ефективної діяльності у певній галузі. Водночас, аналіз наукової літератури із даного проблемного питання дозволяе виділити ще кілька підходів у визначенні поняття компетентності. Отже, iї інтерпретують, поперше, як здатність, здібність; по-друге, як сукупність досвіду; по-третє, як набір умінь, навичок; по-четверте, як єдність психічних властивостей; по-п'яте, як ефективну модель дії. Ми, як і більшість науковців, погоджуємось 3 думкою, що компетентність охоплює не лише комплекс знань, сукупність вмінь та навичок, а й уміння застосовувати отримані теоретичні знання у практичному житті [7]. До речі, на щорічному Всесвітньому економічному форумі у Давосі, Швейцарія, найактуальнішими професійними навичками серед інших були визнані комплексне багаторівневе рішення проблем, критичне мислення, когні- 
тивна гнучкість, креативність, уміння керувати людьми, успішна взаємодія, емоційна компетентність, формування власної думки та самостійне прийняття рішень.

Таким чином, виходячи 3 зазначених вище поглядів, можемо з впевненістю констатувати, що компетентність визначається як отриманий досвід, як тривалий процес набуття умінь та навичок, необхідних для досягнення високого рівня майстерності у певній сфері життєдіяльності, зокрема професійній. Таке трактування дає нам можливість звернутися до вивчення проблеми професійної компетентності особистості майбутнього фахівця.

Враховуючи специфіку професійної діяльності лікаря, важливим фактором іiї ефективності є професійна компетентність. 3 огляду на це, доцільно припустити, що основним завданням навчання і виховання, результатом професійного становлення фахівця у вищому медичному навчальному закладі є формування професійної компетентності студентівмедиків.

Відповідно до концепції професійного розвитку особистості, професіоналізм лікаря включає не лише ефективне виконання своєї професійної діяльності, а й зрілість особистості фахівця, поєднання професійно важливих якостей з психологічними у процесі кваліфікованої лікувальної взаємодії.

Аналіз світових тенденцій у галузі професійної медичної освіти засвідчує зростання вимог до професіоналізму та особистих якос- тей лікаря. Слід зазначити, що професіоналізм лікаря зумовлюється рівнем його компетентності, що є однією з найважливіших особистісних якостей. Професійна компетентність лікаря - це комплекс набутих у процесі професійної підготовки знань, вмінь та навичок, необхідних для виконання своїх професійних обов'язків.

Період навчання у вищій медичній школі відіграє особливу роль у процесі формування особистості лікаря, саме тому, на наше глибоке переконання, питання особистісного становлення фахівця, зокрема лікаря, 3 точки зору, їх майбутньої професійної діяльності має постійно знаходитись у центрі уваги. 3 цією метою навчально-виховний процес підготовки майбутнього лікаря має передбачати не лише професійний, а й особистісний розвиток фахівця, як на етапі додипломної, так i на етапі післядипломної підготовки.

Професійне становлення особистості лікаря відбувається не лише під час навчання у вищому медичному навчальному закладі. Велику роль відіграють якості особистості, які розвиваються та вдосконалюються у процесі здобуття освіти та у подальшій трудовій діяльності. Професійне становлення майбутнього лікаря є поетапним моментом індивідуальноособистісного розвитку фахівця.

Здійснений у попередніх наших дослідженнях аналіз концепцій та моделей професійно-особистісного розвитку та становлення фахівців на етапі фахової підготовки, дозво- 
лив визначити та окреслити кілька етапів професіогенезу особистості лікаря від етапу професійної психологічної готовності та адаптації до етапу професійної майстерності, джерелом якої виступають не лише особисті якості лікаря, а і його професійні компетенції.

Перший важливий етап - це професійне самовизначення майбутнього лікаря, врахування його професійних інтересів, нахилів. Він включає вибір професійної освіти і рівень професійної підготовки. Другий етап - це процес професійної підготовки студента-медика, оволодіння професійними знаннями. Третій етап, коли випускник розпочав практичну діяльність, в тому числі професійне навчання в інтернатурі. У нього є можливість застосовувати набуті теоретичні знання, вдосконалити свої вміння та відпрацьовувати навички. Важливими $є$ психологічна готовність до професійної діяльності та усвідомлення професійної ідентичності майбутнім лікарем. Четвертий етап - виконання професійних обов'язків. Це період набуття власного досвіду, самостійного виконання кваліфікованої професійної діяльності, формування професійних компетентностей, власного професіоналізму, проектування кар'єрного зростання. Важливими є подальший професійний саморозвиток та самовдосконалення. П'ятий етап - висококваліфікована діяльність, професійна мобільність, професійна майстерність.

Професійне становлення лікаря, 3 нашої точки зору, передбачає формування про- фесійно важливих знань, вмінь, навичок, індивідуальних властивостей та способів виконання професійних обов'язків у процесі лікувальної взаємодії. В цілому, можна виділити основні складові професійного становлення лікаря. По-перше, спрямованість особистості, що включає мотиви, ціннісні орієнтації, соціально-професійний статус тощо. По-друге, професійна компетентність - сукупність професійних знань, вмінь та навичок, способів виконання професійної діяльності. По-третє, професійно важливі якості лікаря.

Загалом, праця лікаря є багатоаспектною діяльністю, яка, на нашу думку, включає декілька складових: професійну спрямованість, соціальну взаємодію, комунікативні здібності; особистісні якості фахівця, його емоційно-психологічні властивості, які є взаємодоповнюючими та спрямовані на допомогу пацієнтові. У зв'язку з цим в цілому можна виділити інтегральні характеристики професійної діяльності лікаря і констатувати, що професіоналізм лікаря має визначати співвідношення, 3 одного боку, його професійних знань, вмінь та навичок, а, з іншого - психологічних властивостей. В свою чергу, такий підхід дозволяє нам стверджувати, що професійна компетентність лікаря, як невід'ємна характеристика його професійної діяльності, 3 нашої точки зору, складається з кількох важливих компетентностей: фахова компетентність; соціальна компетентність; комунікативна компетентність; особистісно-індивідуальна ком- 
петентність; емоційна компетентність [7].

Професійна компетентність лікаря - це єдність його теоретичної і практичної готовності до здійснення професійної діяльності. Професійна готовність, в свою чергу, складається із суми знань, вмінь та навичок, закономірностей розвитку та становлення особистості фахівця. При цьому, спеціальні знання $\epsilon$ необхідною, але недостатньою умовою професійної компетентності. Важливими є професійні вміння та навички, що, звичайно, грунтуються на теоретичних знаннях, через які і розкривається структура професійної компетентності лікаря. Зміст професійної компетентності лікаря виявляється в узагальненому умінні професійно діяти, що, передбачає наявність у лікаря аналітичних (аналізувати, осмислювати, правильно діагностувати, формулювати завдання, знаходити способи оптимального лікування тощо); прогностичних (пов'язані 3 управлінням лікувальним процесом, передбачають чітку уяву про мету діяльності, очікуваний результат, передбачення не прогнозованих результатів, визначення етапів лікувального процесу, його прогнозування тощо); рефлексивних (спрямовані на себе, розуміння i аналіз власних дій, вчинків); комунікативних (вміння вербального спілкування); перцептивних (допомагають розуміти інших) вмінь, а також вмінь професійної взаємодії (вміння встановлювати стосунки, обирати до пацієнтів, колег найдоцільніші способи поведінки, звертань, розподіляти увагу, забезпечувати сприятливу атмосферу) тощо. Для лікаря важливо встановити рівень результативності власної діяльності: адекватність і правильність комплексу визначених завдань, втручань; ефективність методів діагностики, прийомів лікування; відповідність застосовуваних форм індивідуальним, віковим, іншим особливостям пацієнтів; причини успіхів, помилок, невдач, труднощів у процесі лікувальної взаємодії тощо.

Суспільна значущість і складність професійних обов'язків лікаря вимагають від нього високого рівня професійної підготовки, фундаментальних знань теорії та практики медицини, опанування навичками, тактикою, відповідними методами та прийомами лікарської діяльності.

Лікар повинен підтримувати й удосконалювати свої знання та навички, докладати необхідних зусиль до професійного самовдосконалення на рівні сучасного стану медицини. У своїй роботі лікар має керуватися сучасними стандартами обстеження та лікування. Лікар зобов'язаний незалежно від сфери своєї переважної спеціалізації, якщо така має місце, бути компетентним у загально-медичних питаннях, питаннях невідкладної допомоги та термінальних станів. Лікар, який бере участь у санітарно-просвітницькій діяльності, повинен користуватися науково підтвердженими даними, проявляти обачливість і брати до уваги можливі наслідки своїх висловлювань перед громадськістю. При цьому необхідно уникати 
вчинків рекламного характеру як на свою особисту користь, так і на користь установ і організацій, які лікар представляє, на користь справи $з$ негативними наслідками. Якщо лікар пропагує у медичному середовищі недостатньо перевірений діагностичний або лікувальний метод, він зобов'язаний супроводжувати своє повідомлення необхідними застереженнями. Подібні повідомлення неприпустимі поза медичним середовищем.

В цілому, зміст професійної компетентності лікаря виявляється в узагальненому умінні професійно діяти, що, передбачає наявність у лікаря аналітичних (аналізувати, осмислювати, правильно діагностувати, формулювати завдання, знаходити способи оптимального лікування тощо); прогностичних (пов'язані з управлінням лікувальним процесом, передбачають чітку уяву про мету діяльності, очікуваний результат, передбачення не прогнозованих результатів, визначення етапів лікувального процесу, його прогнозування тощо); рефлексивних (спрямовані на себе, розуміння і аналіз власних дій, вчинків); комунікативних (вміння вербального спілкування); перцептивних (допомагають розуміти інших) вмінь, а також вмінь професійної взаємодії (вміння встановлювати стосунки, обирати до пацієнтів, колег найдоцільніші способи поведінки, звертань, розподіляти увагу, забезпечувати сприятливу атмосферу) тощо. Для лікаря важливо встановити рівень результативності власної діяльності: адекватність і правиль- ність комплексу визначених завдань, втручань; ефективність методів діагностики, прийомів лікування; відповідність застосовуваних форм індивідуальним, віковим, іншим особливостям пацієнтів; причини успіхів, помилок, невдач, труднощів у процесі лікувальної взаємодії тощо.

Фахова компетентність лікаря обумовлена володінням ним знаннями, практичним досвідом у певній галузі медицини (анестезіологія, гематологія, гінекологія, дерматологія, ендокринологія, імунологія, кардіологія, неврологія, нефрологія, онкологія, ортопедія, педіатрія, ревматологія, стоматологія, терапія, хірургія та ін.). Це особистісна професійна якість лікаря, яка дозволяє йому самостійно та ефективно реалізовувати цілі лікувального процесу, лікувальної взаємодії. Це здатність до кваліфікованого вирішення широкого кола професійних завдань. Для цього потрібно не лише володіти знаннями, а й вміти i бути готовим грамотно застосовувати їх у практичній професійній діяльності. Компетентність лікаря у професійній діяльності включає в себе професійні знання вміння та навички; професійну обізнаність; професійні позиції, професійно-важливі якості; професійне мислення; професійну пильність; професійне прогнозування; розуміння і збереження моральних цінностей тощо. Соціальна компетентність лікаря містить: вміння встановлювати контакти; терпимість у стосунках 3 іншими; використання відкритої позиції у лікувальній 
взаємодії; вибір доречної стратегії поведінки; готовність до співпраці, відкритість у встановленні контактів з іншими людьми, відверта взаємодія 3 ними тощо. Комунікативна компетентність лікаря охоплює знання про професійну етику та деонтологію; навички у професійному спілкуванні; професійний такт; розуміння особливостей свого індивідуального стилю спілкування; розуміння пацієнта; доброзичливе ставлення до нього; щирість тощо. Особистісно-індивідуальну компетентність лікаря утворюють психологічні знання про особистість; усвідомлення своєї індивідуальності; власні здібності; особистісна рефлексія; вміння бачити сильні і слабкі сторони своєї діяльності; вміння реалізовувати плани свого особистісного розвитку тощо. Зрілість особистості фахівця зміцнює його особистісноіндивідуальну компетентність. Емоційна компетентність представлена системою знань про емоції, їх розвиток; вміннями та способами аналізу емоцій; усвідомленням своїх емоцій та емоцій інших людей, умінням визначити їх, управляти власними емоціями та емоціями інших людей, визначати джерело та причину їх виникнення, а також адекватним вираженням емоцій (навички рефлексії, саморегуляції та експресивності), розвиток яких в цілому сприяє емоційній відкритості та емоційній емпатії лікаря $[5,6]$.

Висококваліфікований лікар, який постійно взаємодіє, контактує з іншими, складне i динамічне життя якого накладає високі ви- моги до його особистості, має бути освіченою людиною не лише в галузі загальних і спеціальних здібностей, а й бути психологічно обізнаним, адже лікареві часто доводиться переживати стресові ситуації, зустрічатись з болем, стражданнями, смертю людей, іноді відчувати себе, на жаль, безсилим перед обставинами.

Таким чином, професійна компетентність як характеристика особистості лікаря відображає не стільки рівень знань фахівця, скільки вміння ці знання застосовувати на практиці, у новій ситуації, моделювати їх для досягнення високих результатів у професійній діяльності.

В нашій моделі процес формування основних структурних компонентів професійної компетентності лікаря складається 3 кількох етапів [7]. Так, на першому етапі (теоретична підготовка) відбувається оволодіння студентами-медиками теоретичними i емпіричними знаннями; другий етап (практична підготовка) спрямований на оволодіння студентамимедиками теоретичними і емпіричними знаннями, застосування студентами набутих знань, формування вмінь і навичок у навчальнопізнавальному процесі; на третьому етапі (клінічна підготовка, інтернатура) відбувається застосування набутих знань, корекція умінь і відпрацювання навичок у процесі практичної професійної діяльності, в клініці.

Висновки. Детальний аналіз психологічних особливостей професійного становлен- 
ня майбутнього лікаря дозволяє нам говорити про можливість розвитку професійної компетентності фахівця. Спираючись на цей аналіз, можемо припустити, що здобуття знань, вмінь та навичок, пов'язаних з професійною компетентністю лікаря, може сприяти розвитку професіоналізму, як інтегральної якості особистості фахівця. Таким чином, логіка побудови нашої концепції професійного становлення особистості лікаря дозволяє зробити висновки, що професіогенез особистості лікаря та його професіоналізм реалізуються у професійній діяльності. Кожний етап професійного становлення характеризується своєрідним співставленням особистісних та професійних особливостей, що виявляються у процесі професійної діяльності, яка, в свою чергу, вимагає сформованої професійної компетентності лікаря.

\section{Перспективи подальших розвідок.} Результати проведеного нами дослідження 3 проблеми професійного розвитку особистості, формування професійної компетентності фахівця у вищому медичному навчальному закладі диктують нагальну необхідність продовження і подальшого вивчення особливостей професіогенезу лікаря.

\section{Перелік використаних джерел:}

1. Вітковська О. I. Професійне самовизначення особистості і практичні аспекти професійної консультації. К.: Наук. світ, 2001. - 91 с.

2. Зеєр $Е$. Ф. Психология профессионального развития: уч. пособие для студ. высш. уч. заведений /Е.Ф. Зеєр. -

DOI (Article): https://doi.org/10.31108/2018vol13iss3pp67-85
М.: Издательский центр «Академия», 2007.

3. Климов E. A. Индивидуальный стиль деятельности // Психология индивидуальных различий. Тексты / Под ред. Ю.Б. Гиппенрейтер, В.Я. Романова. - М.: Изд-во МГУ, 1982.

4. Кокун О. М. Оптимізація адаптаційних можливостей людини: психофізіологічний аспект забезпечення діяльності: Монографія. - К.: Міленіум, 2004.

5. Лазуренко О. О. Аналіз передумов формування емоційної сфери та проявів емоційного потенціалу особистості студента в процесі професійної підготовки / О.О. Лазуренко // Молодий вчений. - № 5, травень 2014. - С. 127-131.

6. Лазуренко О. О. До питання щодо розвитку поняття «емоційна компетентність» у психології / О.О. Лазуренко // Науковий огляд. - №1 (11). - Київ, 2015. - С. 116123.

7. Лазуренко О. О. Психологічні особливості формування емоційної компетентності майбутнього лікаря: дис. ... канд. психол. н. : 19.00.07. - Київ, 2017. - 270 с.

8. Лазуренко О. О. Тенденції модернізації професійнопсихологічної підготовки лікарів: компетентнісний підхід / О.О. Лазуренко // Психологічний часопис. - №1 (11) 2018. - C. 87-100.

9. Ломов Б. Ф. Методологические и теоретические проблемы психологии / Б.Ф. Ломов. - М.: Наука, 2008.

10.Маркова А.К. Психология профессионализма. - М.: РАГС, 2006.

11. Пряжников Н. С. Профессиональное и личностное самоопределение. - М.: Изд-во «Институт практической психологи»; Воронеж: НПО "МОДЭК". - 1996.

12. Психология труда: Учеб. для вузов / под ред. А.В. Карпова. - М.: Владос-пресс, 2005.

13. Толочек B. A. Современная психология труда. СПб.: Питер, 2005.

14. Тертична Н. А., Лазуренко О.О. Компетентність як ціннісна орієнтація у професійній підготовці медичного психолога / О. О. Лазуренко, Н.А. Тертична // Особистість та її історія: 3б. матеріалів VII Міжнародної науково-практичної конференції. - Ніжин, 2017. - С. 103- 
105.

15. Lazurenko O. O., Smila N. V. Psychological and Pedagogical Principles of Students' Emotional Sphere formation in the Process of Professional Training and Development / O. Lazurenko, N. Smila // Journal of Psychological Sciences. - Vol.2, No. 3, 2016. - P.124-129.

\section{References (Transliteration):}

1. Vitkovs'ka O. I. Profesijne samoviznachennya osobistosti i praktichni aspekti profesijnoï konsul'taciï. K.: Nauk. svit, 2001. - $91 \mathrm{~s}$.

2. Zeer E. F. Psihologiya professional'nogo razvitiya: uch. posobie dlya stud. vyssh. uch. zavedenij /E.F. Zeєr. - M.: Izdatel'skij centr «Akademiya», 2007.

3. Klimov E. A. Individual'nyj stil' deyatel'nosti // Psihologiya individual'nyh razlichij. Teksty / Pod red. YU.B. Gippenrejter, V.YA. Romanova. - M.: Izd-vo MGU, 1982.

4. Kokun O. M. Optimizaciya adaptacijnih mozhlivostej lyudini: psihofiziologichnij aspekt zabezpechennya diyal'nosti: Monografiya. - K.: Milenium, 2004.

5. Lazurenko $O$. O. Analiz peredumov formuvannya emocijnoï sferi ta proyaviv emocijnogo potencialu osobistosti studenta $\mathrm{v}$ procesi profesijnoï pidgotovki / O.O. Lazurenko // Molodij vchenij. - № 5, traven' 2014. - S. 127 $-131$.

6. Lazurenko $O$. $O$. Do pitannya shchodo rozvitku ponyattya «emocijna kompetentnist'» u psihologiï / O.O. Lazurenko // Naukovij oglyad. - №1 (11). - Kiïv, 2015. S. 116-123.

7. Lazurenko O. O. Psihologichni osoblivosti formuvannya emocijnoï kompetentnosti majbutn'ogo likarya: dis. ... kand. psihol. n. : 19.00.07. - Kiïv, 2017. - 270 s.

8. Lazurenko $O$. O. Tendenciï modernizaciï profesijnopsihologichnoï pidgotovki likariv: kompetentnisnij pidhid / O.O. Lazurenko // Psihologichnij chasopis. - №1 (11) 2018. - C. 87-100.

9. Lomov B. F. Metodologicheskie i teoreticheskie problemy psihologii / B.F. Lomov. - M.: Nauka, 2008.

10.10. Markova A.K. Psihologiya professionalizma. - M.: RAGS, 2006.

11. Pryazhnikov N. S. Professional'noe i lichnostnoe samoopredelenie. - M.: Izd-vo «Institut prakticheskoj psihologi»; Voronezh: NPO "MODEHK". - 1996.

12. Psihologiya truda: Ucheb. dlya vuzov / pod red. A.V. Karpova. - M.: Vlados-press, 2005.

13. Tolochek $V$. A. Sovremennaya psihologiya truda. SPb.: Piter, 2005.

14. Tertichna N. A., Lazurenko O.O. Kompetentnist' yak cinnisna orientaciya u profesijnij pidgotovci medichnogo psihologa / O. O. Lazurenko, N.A. Tertichna // Osobistist' ta iii istoriya: Zb. materialiv VII Mizhnarodnoï naukovopraktichnoï konferenciï. - Nizhin, 2017. - S. 103-105.

15. Lazurenko O. O., Smila N. V. Psychological and Pedagogical Principles of Students' Emotional Sphere formation in the Process of Professional Training and Development / O. Lazurenko, N. Smila // Journal of Psychological Sciences. - Vol.2, No. 3, 2016. - P.124-129.

\section{Lazurenko Olena}

Ph. D. in Psychology, Senior Lecturer, Department of General and Medical Psychology and Pedagogics, Bogomolets National Medical University, Kyiv (Ukraine)

\section{PSYCHOLOGICAL AND PEDAGOGICAL FEATURES OF PROFESSIONAL COMPETENCE MODELING IN PROFESSIONAL DEVELOPMENT OF MEDICAL STUDENTS}

\section{ABSTRACT}

The article is devoted to the problem of professional development of a specialist. One of the tasks of the system of national higher education is the training of highly skilled specialists. The analysis of scientific sources suggests that the problem of studying professional develop- 
ment is in the constant focus of many scholars who determine the nature and stages of professional development, psychological peculiarities, psychological and pedagogical conditions and factors of professional development of the individual. The problem of studying the peculiarities of the professional competence of doctors in the process of professional development and its influence on professional activity remains insufficiently investigated, and the insufficient level of development of professional competence of graduates of medical universities negatively affects the effectiveness of future professional activities. The formation of professionalism of a future specialist depends on educational and cognitive activity, which encompasses not only mastering of the system of knowledge, acquisition of skills and abilities, but also constant self-improvement. The essence and stages of professional formation are determined. Professional formation of a personality is a holistic dynamic process from the formation of professional self-determination to the full realization of oneself in the activity. Professional formation of the person has two vectors educational and personal growth. Professionalism is an indispensable component of competence in a particular activity. The stages of development of the doctor in the professional sphere, stages of formation of professional abilities in the process of mastering the profession are considered. The general characteristic of professional formation and level of professionalism is given. Competence is defined as the acquired experience as a long process of acquiring the skills and skills necessary to achieve a high level of mastery in a particular area of life, in particular professional. Given the specifics of the professional activities of the doctor, an important factor in its effectiveness is professional competence. The main task of training and education, the result of professional development of a specialist in a higher medical school is the formation of professional competence of medical students. The professional competence of a doctor is a complex of skills acquired in the process of training the knowledge, skills and abilities necessary for the performance of their professional duties. The model of professional formation and formation of professional competence of the future doctor is presented. The analysis of stages of professional formation of specialists is presented, psychological and pedagogical peculiarities of formation of professional competence of future physicians at the stage of professional formation are determined. The stages of professional psychology of the personality of the doctor from the stage of professional psychological readiness and adaptation to the stage of professional skill are outlined. Analyzed psychological and pedagogical peculiarities of the professional formation of the future physician allow us to talk about the possibility of developing professional competence of a specialist. Educational process of preparation of the future doctor should provide not only professional, but also personal development of a specialist, both at the stage of pre-diploma, and at the stage of postgraduate 
training. The analysis of the concepts and models of professional and personal development and the formation of specialists at the stage of professional training was carried out in our previous studies. It allowed identifying and outlining several phases of the person's professional psychology from the stage of professional psychological readiness and adaptation to the stage of professional mastery, the source of which is not only the personal qualities of the doctor, but also his professional competencies.

A detailed analysis of the psychological peculiarities of the professional development of a future physician allowed us to talk about the possibility of developing professional competence of a specialist. Based on this analysis, it can be assumed that the acquisition of knowledge, skills and abilities associated with the professional competence of a doctor will promote the development of professionalism as an integral quality of the personality of a specialist. The concept of professional development of the physician's personality allows us to conclude that the professionalism of the personality of the doctor and his professionalism are realized in professional activity. Each stage of professional development is characterized by a peculiar combination of personality and professional features, which are manifested in the process of professional activity, which, in turn, requires the former professional competence of the doctor. The results of the research on the problem of professional development of the individual, the formation of professional competence of a specialist in a higher medical school dictate the urgent need for continuation and further study of the features of the doctor's professional training.

Key words: professional formation, profession genesis, professional competence, professionalism, professional training, personality of the future doctor.

\section{Лазуренко Елена Алексеевна}

Кандидат психологических наук, старший преподаватель кафедры общей и медищинской психологии и педагогики Национального медицинского университета имени А. А. Богомольцุа, г. Киев (Украина)

\section{ПСИХОЛОГО-ПЕДАГОГИЧЕСКИЕ ОСОБЕННОСТИ МОДЕЛИРОВАНИЯ ПРОФЕССИОНАЛЬНОЙ КОМПЕТЕНТНОСТИ СТУ ДЕНТОВ-МЕДИКОВ В ПРОЦЕССЕ ПРОФЕССИОНАЛЬНОГО СТАНОВЛЕНИЯ}

Аннотация. Статья посвящена проблеме профессионального становления специалиста. Одной из задач системы национального высшего образования является подготовка высококвалифицированных специалистов. Анализ научных источников свидетельствует о том, что проблема исследования профессионального становления находится в постоянном центре внимания многих ученых, которые определяют сущность и этапы профессионального становления, психологические особенности, психолого-педагогические условия и факторы профессионального развития личности. Проблема исследования особенностей профес- 
сиональной компетентности врачей в процессе профессионального становления и ее влияния на профессиональную деятельность остается недостаточно исследованной, а недостаточный уровень развития профессиональной компетентности выпускников медицинских университетов негативно влияет на эффективность будущей профессиональной деятельности. Становление профессионализма будущего специалиста зависит от учебнопознавательной деятельности, которая охватывает не только овладение системой знаний, приобретения умений и навыков, но и постоянное самосовершенствование. Определена сущность и этапы профессионального становления. Профессиональное становление личности - это целостный динамичный процесс от формирования профессионального самоопределения до полной реализации себя в деятельности. Профессиональное становление личности имеет два вектора - образовательный и личностного роста. Профессионализм - непременная составляющая компетентности в конкретной деятельности. Рассмотрены стадии развития врача в профессиональной сфере, этапы формирования профессиональных способностей в процессе овладения профессией. Приведена общая характеристика профессионального становления и уровня профессионализма. Компетентность определяется как полученный опыт, как длительный процесс приобретения умений и навыков, необходимых для достижения высокого уровня мастерства в определенной сфере жизнедеятельности, в том числе профессиональной. Учитывая специфику профессиональной деятельности врача, важным фактором ее эффективности является профессиональная компетентность. Основной задачей обучения и воспитания, результатом профессионального становления специалиста в высшем медицинском учебном заведении является формирование профессиональной компетентности студентов-медиков. Профессиональная компетентность врача - это комплекс приобретенных в процессе профессиональной подготовки знаний, умений и навыков, необходимых для выполнения своих профессиональных обязанностей. Представлена модель профессионального становления и формирования профессиональной компетентности будущего врача. Представлен анализ этапов профессионального становления специалистов, определены психологопедагогические особенности формирования профессиональной компетентности будущих медиков на этапе профессионального становления. Определены этапы профессиогенеза личности врача от этапа профессиональной психологической готовности и адаптации к этапу профессионального мастерства. Проанализировано психолого-педагогические особенности профессионального становления будущего врача позволяют говорить о возможности развития профессиональной компетентности специалиста. Учебно-воспитательный процесс подготовки будущего врача должна 
предусматривать не только профессиональный, но и личностное развитие специалиста, как на этапе додипломного, так и на этапе последипломной подготовки. Проведенный в предыдущих наших исследованиях анализ концепций и моделей профессиональноличностного развития и становления специалистов на этапе профессиональной подготовки, позволил определить и выделить несколько этапов профессиогенеза личности врача: от этапа профессиональной психологической готовности и адаптации к этапу профессионального мастерства. Детальный анализ психологических особенностей профессионального становления будущего врача позволил говорить о возможности развития профессиональной компетентности специалиста. Опираясь на этот анализ, можно предположить, что получение знаний, умений и навыков, связанных с профессиональной компетентностью врача, будет способствовать развитию профессионализма, как интегрального качества личности специалиста. Концепция профессионального становления личности врача позволяет сделать выводы, что профессиогенез личности врача и его профессионализм реализуются в профессиональной деятельности. Каждый этап профессионального становления характеризуется своеобразным сопоставлением личностных и профессиональных особенностей, проявляющихся в процессе профессиональной деятельности, которая, в свою очередь, требует сложившейся профессиональной компе- тентности врача. Результаты проведенного исследования по проблеме профессионального развития личности, формирования профессиональной компетентности специалиста в высшем медицинском учебном заведении диктуют настоятельную необходимость продолжения и дальнейшего изучения особенностей профессиогенеза врача.

Ключевые слова: профессиональное становление, профессиогенез, профессиональная компетентность, профессионализм, профессиональная подготовка, личность будущего врача.
Дата отримання статті: 17.03 .2018

Дата рекомендації до друку: 23.03.2018 